\title{
屯田兵村の空間構成と現代コミュニティとの関係 \\ 一敷地間通路を中心とした隣家間の環境形成に着目してー \\ THE RELATIONSHIP BETWEEN COMMUNITY OF TODAY AND SPATIAL STRUCTURE OF TONDENHEI-MURA
}

Focusing on the environmental formation between next-door neighbors at passages on the site

\author{
大槻 政洋*, 森傑** \\ Masahiro OOTSUKI and Suguru MORI
}

\begin{abstract}
The purpose of this study is to grasp the relationship between next-door neighbors in the linear rural settlement aiming at passages on the site, Yoko-michi in Tondenhei-mura, and to comprehend effects of spatial structure in community of today. The results are as follows; 1) Inhabitants make their residential environment effective by arranging the passage "Yoko-michi" to promote communication with next-door neighbors. 2) The farmer and non-farmer relationship has coming and going to borrow or lend farmlands and agricultural facilities. 3) Spatial structure as the linear rural settlement has positive effects that inhabitants form their environment in community of today.
\end{abstract}

Keywords: tondenhei-mura, spatial structure, next-door neighbor, environmental formation, community 屯田兵村, 空間構成, 隣家, 環境形成, コミュニティ

\section{1. はじめに}

\section{1-1. 背景と目的}

現代の日本の農村集落が共通して抱える問題に、農業従事者の高 齢化や農業従事継承者の減少・不足などが挙げられる。これらの問 題は、単に産業基盤としての農村集落を支えることが難しくなると いう状況をつくり出すだけでなく、非農業従事者を含む農村の現代 コミュニティの本質的な変化へも大きな影響を及ぼしつつある。 北海道開拓時に形成された屯田兵村は、明治 6 年から計画的につ くられた列居型の集落である。この屯田兵村は、純粋な農業への従 事というよりも兵役の一環として開拓された集落であるため、当時 の兵役制度やシステムがそのまま敷地形状に反映されているという 特徴を持つ。一兵士をそれぞれ均等に扱い管理するという兵役シス テムのため、そこに住む屯田兵のための兵屋や敷地も均等に配分さ れ、列状に配置された。明治 37 年に屯田兵制度が廃止され兵役と してのシステムがなくなった後も、その敷地形状は明確に残り、現 在においても屯田兵村独特の景観をなしている。この当初の兵役と いう特別な目的により計画的に敷地形状と建物配置が決められた集 落において、今日の農業とその生活と照らし合わせたとき、何らか の影響あるいは課題を生じている可能性は容易に想定できる。例え ば、自然発生的に形成された集落に比べ、居住者は農業を行う上で、
そしてなにより隣家および地域社会との関係を築く上で、兵役シス テムに則って計画された既存環境に対して積極的に手を加え、現代 生活になじむような環境の形成を試みてきたと考えられる。そし て、今日の農村生活およびそのコミュニティの本質は、現代とは全 く異なるコンテクストが強く物理的環境として反映された屯田兵村 においてこそ、居住者の既存環境への能動的な働きかけというかた ちで顕著に現れていると考えられる。

そこで本研究は、計画的な空間秩序をもってつくられた列居型集 落に始まる旧屯田兵村地域を対象とし、開拓当時の計画性とその空 間構成が現代の居住者の能動的な環境形成活動を誘発しているとの 仮説のもと、開拓当時からの空間構成の特徵的な要素の一つである 隣家への敷地間通路「横道」に着目し、それが今日どのように機能 しているのかを詳細に分析することで、屯田兵村の計画的な初期条 件が現代コミュニティに対して与えている影響について考察するこ とを目的とする。

\section{1-2. 既往研究と本研究の位置づけ}

農村集落におけるコミュニティに関する研究については、これま で数多くの成果と蓄積がみられる。例えば、伊藤は、農村における 班・祭事・血縁・隣近所といった様々な人々の社会的な繋がりが、 重層的・複合的に集落空間に対応しつつ継承されていることを明ら 
かにしている ${ }^{1)}$ 。歴史的社会集団の空間的重層性を取り上げている 点で興味深いが、近年の兼業化や混住化といった農村集落の課題に ついては考察されていない。混住化については、鎌田らが、首都圈 における混住地域について類型化を行い、農村集落のコミュニティ や居住者交流の現状に関する意識調查を実施、今後の人口減少によ るコミュニティ衰退の課題を提示しているが、明らかとなった集落 の居住者の意識と空間構成との関連性については必ずしも十分には 議論されていない ${ }^{2)}$ 。一方、屯田兵村に関しては、柳田・重村が、 屯田兵村の計画当初の集落構成や空間構成に関して、これまでの史 料や文献をまとめ計画当初の集落構成や計画原理を分析し、屯田兵 村の当初の計画においてコミュニティ形成も考えられていたと指摘 しているが、現在の空間構成や近隣関係についての考察には及んで いない ${ }^{3,4)}$ 。また、高橋らは、屯田兵の末裔を対象としたパーソナル・ ネットワークの分析を試みているが、集落の空間構成との対応や相 関関係については触れておらず、農村集落がもつ混住化という現象 についても言及してはいない5)。

これらを踏まえ、本研究は、旧屯田兵村地域の現況に焦点を当て、 今日の多様な属性を持った居住者同士のコミュニケーションとそれ と密接に関わるかたちでの環境形成活動を分析し、屯田兵村という 初期条件のもとでの集落空間形成のメカニズムを解明するものとし て位置づけられる。

\section{2. 屯田兵村の開拓時の計画原理}

明治 6 年 (1873 年) に制定された屯田兵制度は、対外的な北方防 衛や北海道内の警備と開拓、また明治維新後の困笨する士族に対す る新たな職業を提供することが目的であった。屯田兵の役割は、軍 隊組織の中隊を単位としながら集落を形成し、地域の警備を行うと ともに、給与された土地に、家族と共に戸建ての兵屋に暮らし、開 墾や営農に従事することであった。この集落が、屯田兵村と称さ れる。明治 37 年 (1904 年) に屯田兵制度が廃止されるまでに、約 70,000ha の未開地が開墾・整備され、37 兵村に兵屋約 7, 300 戸、 家族も含め約 40,000 人が入植することとなった。

その空間構成を集落単位でみると、長方形の耕宅地注 1) の短辺が、 基軸となる道路に接する背割状に規則的に配置され、耕宅地の道路 側に兵屋を一棟ずつ一線に配置するという列居型の集落形態である （図 1）。一方、耕宅地単位でみると、耕宅地の中に建つ兵屋は、基 軸となる前面道路から $15 \sim 25$ 間ほど離れ、奥まった場所に配置さ れている点に特徴がある。図 2 に示すように、基軸道路から兵屋ま で続く「表道」と呼ばれるアプローチ、および、基軸となる前面道

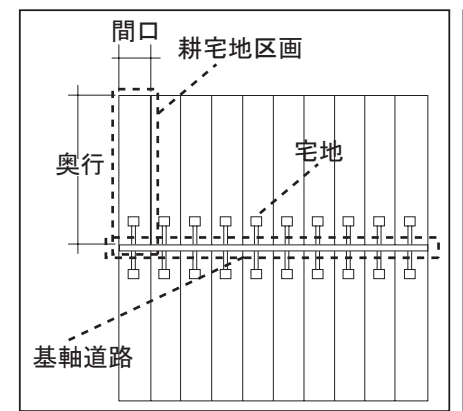

図 1 集落単位の基本パターン

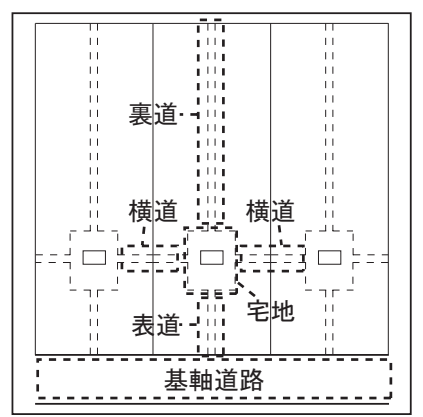

図 2 耕宅地単位の構成
路とは別に、兵屋同士を直接つなぐ通路として「横道」と呼ばれる 通路がある注2)。

これら当時の計画原理については、柳田の研究 ${ }^{3,4)}$ が詳しく、そ れによると、兵屋が基軸道路から離れた位置に建てられた配置計画 の理由について明確に示している史料は発見されていないものの、 村史や現地調查などから、表道の両側のスペースが井戸や風呂等の 共同利用空間、庭木など宅地として活用されていたとされている。 また、当時は、井戸組や風呂組と呼ばれる共同体が存在し、井戸の 水や風呂を共有していたことが明らかにされており、「横道」を利 用した居住者間のコミュニケーションが生まれていたと考えられ る。さらに、兵屋から裏の耕地へ至る道として「裹道」があり、こ れは、現代のように農業機械が発達していない中で、細長い敷地形 状において効率よく農作業を行うためにしつらえられたものと捉え ることができる。

\section{3. 調査方法と結果の概要}

計画的につくられた列居型農村集落である屯田兵村に始まり、今 日も農村として人々の生活が営まれ、かつ、開拓時に最も多かった 間口 30 間の耕宅地をもつ集落に着目し、「茶志内」「光珠内注3)」「当

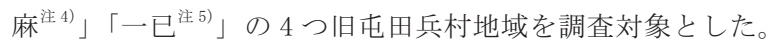

まず、物理的な環境の現状を把握する現地調査を実施した後、隣 家関係の特徵を詳細に把握するため、4 地域のうちで現在も農地の ある敷地に住んでおり、かつ、隣家にも居住者が住んでいる居住者 を対象として、生活実態調查を行った。具体的には、居住者の耕宅 地の建物配置図を作成し、それをもとに生活の仕方や隣家との交流 についての詳細なヒアリングを行った。

その結果、調查対象の条件に当てはまる居住者は、茶志内で 14 件、光珠内で 35 件、一已で 12 件、当麻で 32 件となった。そのうち、 茶志内で 4 件 2 組、光珠内で 12 件 8 組、一已で 4 件 2 組、当麻で 12 件 7 組、合計 32 件 19 組の居住者について、配置図の作成と七 アリングを実施することができた（表 1)。なお、隣家との関係を 把握するために、隣り合った敷地に住んでいる居住者 2 件 1 組を基 本としてしているが、両隣に調査対象がある場合には、2つの組と して分けて、それぞれを一組として分析対象としている。第 5 章以 降、この 32 件 19 組を対象として分析を行う（図 3-1, 2, 3,4)。

\section{4. 敷地内の空間構成}

\section{4-1. 現在の耕宅地単位でみた空間構成のゾーン分類}

旧屯田兵村地域の現在の空間構成の特徵を捉えるために、第 2 章 で概説した計画当初の空間構成の要素とその原理をもとに、前面道 路から表道が続く領域を「表道ゾーン」、農地が広がり裏道が続く 領域を「裏道ゾーン」、その表道と裏道に挟まれた領域を「宅地ゾー ン」と定義した（図 4)。ただし、裏道に関しては、今日ではその 存在が目視では必ずしも明確に確認できない事例もあるため、その

表 1 調查対象の概要

\begin{tabular}{l||c|c||c|c}
\hline 対象地域 & 該当件数 & 該当組数 & 調査件数 & 調査組数 \\
\hline 茶志内 & 14 件 & 8 組 & 4 件 & 2 組 \\
\hline 光珠内 & 35 件 & 20 組 & 12 件 & 8 組 \\
\hline 一 已 & 12 件 & 6 組 & 4 件 & 2 組 \\
\hline 当麻 & 32 件 & 18 組 & 12 件 & 7 組 \\
\hline 合計 & 93 件 & 52 組 & 32 件 & 19 組 \\
\hline
\end{tabular}




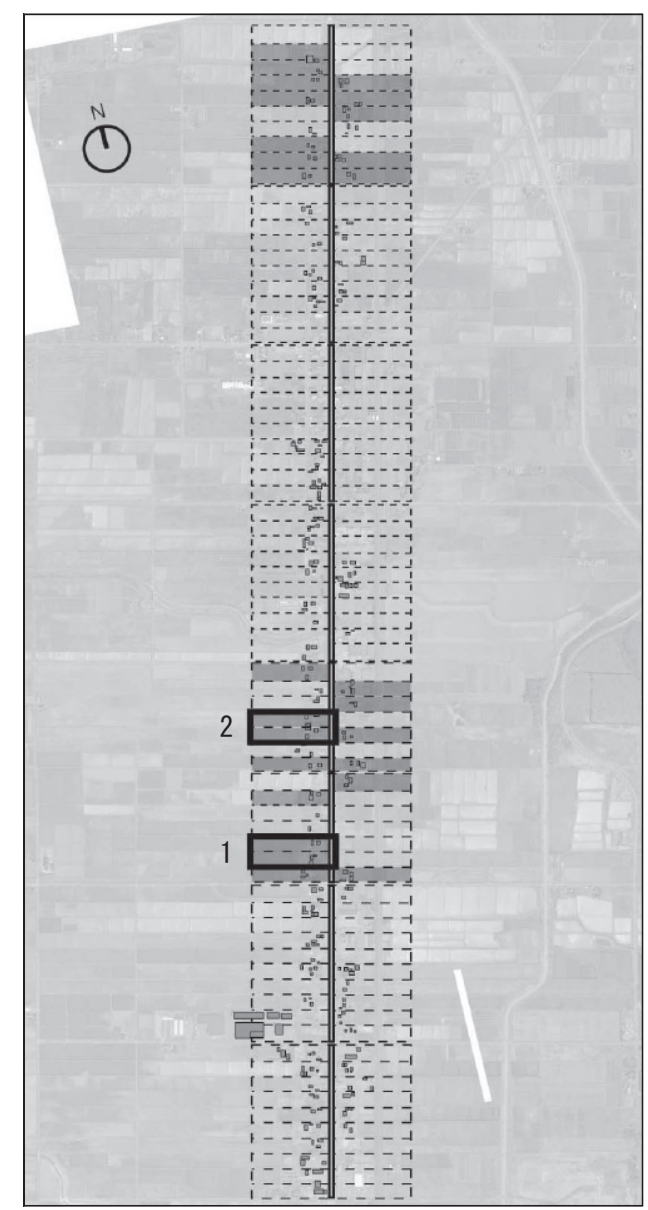

図 3-1 茶志内の現況と分析対象組

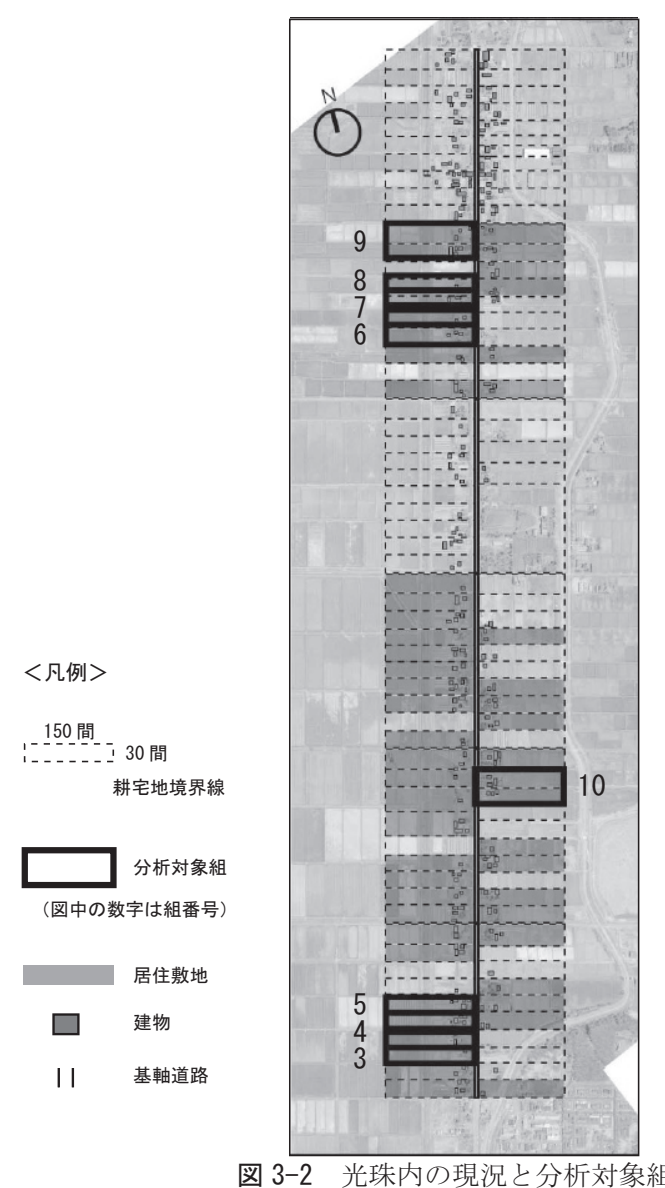

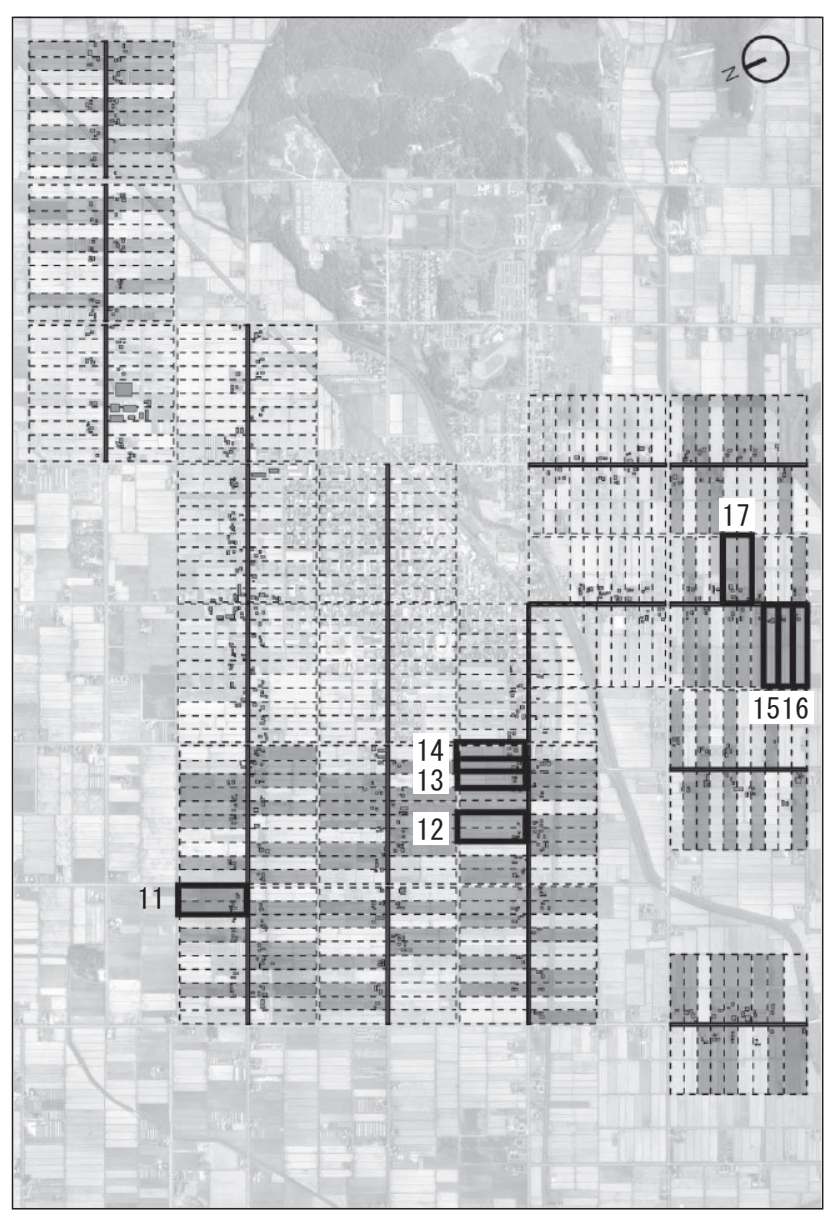

図 3-3 当麻の現況と分析対象組

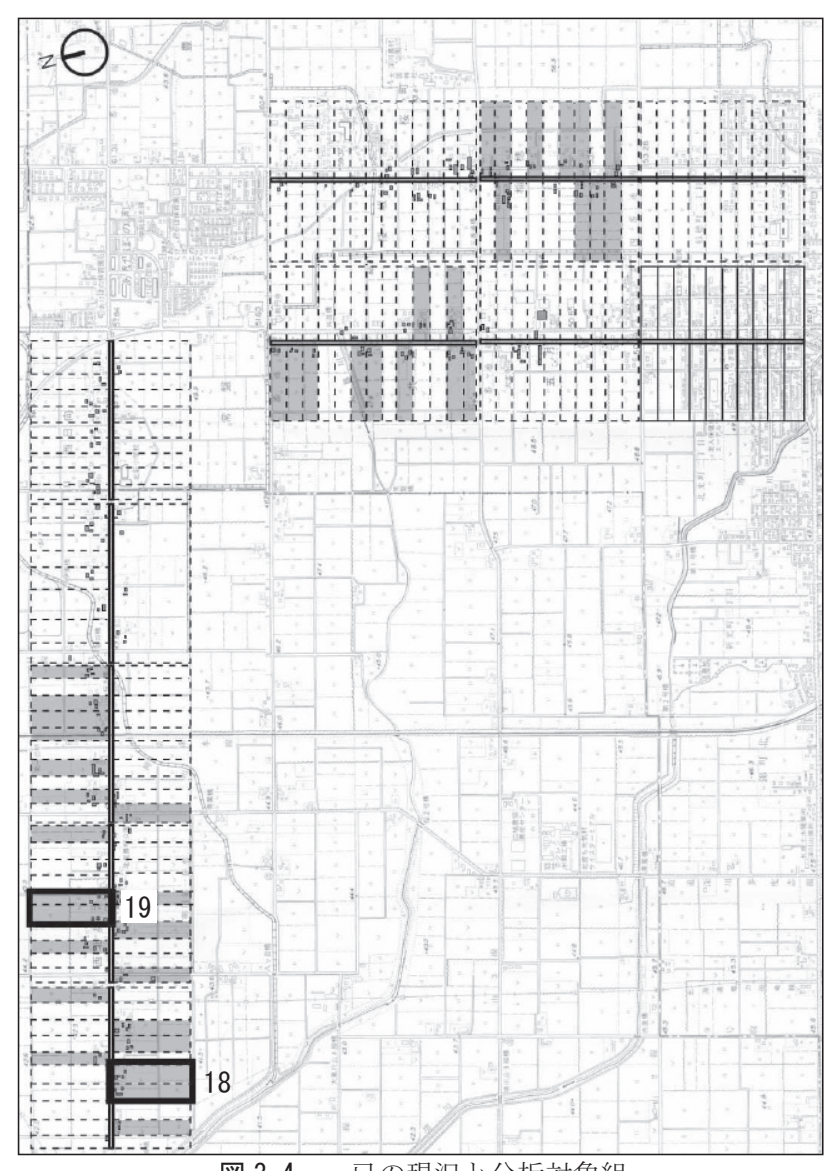

図 3-4 一已の現況と分析対象組 
場合には、現在の敷地内での居住者の生活行動を参考に、農地の端 部でもって領域を確定した。

\section{4-2. 表道ゾーンにおける変化と特徵}

全ての調查対象において、アプローチとしての表道が、その長さ の程度は異なるものの、敷地の間口の中央に位置した状態で残され ていた。また、その両側には、家庭菜園として用いる畑（19 件）や、 樹木等を植えた庭 (10 件) が設けられている事例があった。庭を配 している事例においては、基軸道路からの見た目やその敷地の伝統 を重視して、居住者が庭を整備していることがヒアリングより明ら かとなった。しかし一方、車庫が位置している事例（7 件）や、住 宅が位置している事例 (2 件) も存在した。これらは、冬期間の除 雪の手間を省くといった日常生活での利便性を重視した結果である と考えられる。

\section{4-3. 宅地ゾーンにおける変化と特徵}

宅地ゾーンには、ほとんどの調查対象において、住宅や農業施設 などの建物が配置されている。農業施設の種類や数は、農業従事者 と非農業従事者で大きく異なる。農業従事者は、屋内の作業スペー スや農業機械の格納スペースを確保するために、納屋、倉庫、物置 等の農業施設を複数所有する場合が多い。非農業従事者の中でも離 農した居住者は、かつて利用していた農業施設を解体せずに現在も 所有し、家庭菜園用の資材置き場や物置として利用している場合が 多い。一方、過去にも現在にも農業に従事していない居住者は、農 業施設をいくつか所有し物置として利用している場合と、まったく 所有していない場合が見られた。前者の多くは、農業施設を放置し ていても生活上特に不便を生じるわけではないことから、移住者が そのままの状態で居住している事例である。後者は、農業資材を保 管する必要がないため、不必要な農業施設を積極的に撤去した事例 である。

住宅と農業施設の位置関係については、ほとんどの調查対象にお いて、住宅は農業施設に比べて基軸道路に近い位置に配置されてい た (24 件)。農業施設は農地のある裏道ゾーンに近い場所に位置し ている。敷地の幅や面積という制約があるため、住宅と農業施設群 は近接して配置されている。しかし、その位置関係は農作業の効率 向上を目的としていると考えられる。

また、農業基盤整備注6) のために敷地境界へ水路が設けられたこ とにより、宅地ゾーンにあったと考えられる開拓当時の横道は、ほ とんどの調査対象で存在していなかった。しかしながら、敷地境界 にそれぞれの居住者が、様々な素材で隣家につながる新たな通路を 設けている。これは、第 5 章で定義・分析する敷地間通路の一つで

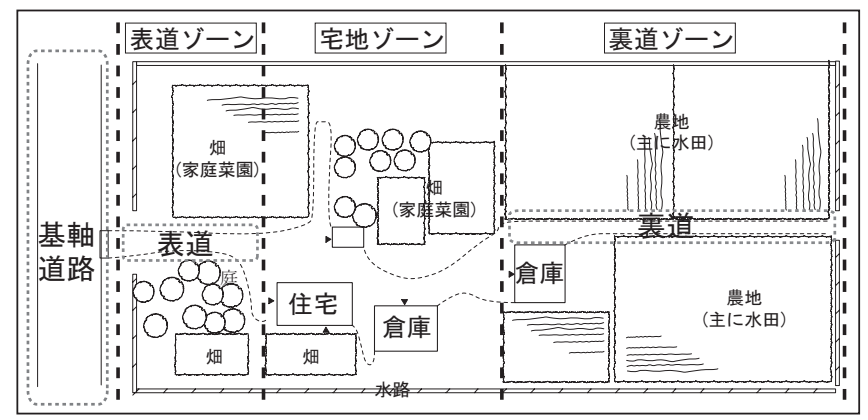

図 4 敷地内の空間構成
ある。

\section{4-4. 裏道ゾーンにおける変化と特徴}

裏道ゾーンでは、開拓当時の裹道が敷地中央に残っている調查対 象がみられた（10 件）。しかし、裏道を敷地の端に移動させている 場合（10 件）や、完全に農地としてしまい裏道を無くしている場 合（12 件）もみられた。裏道が敷地の中央に位置していると、農地 が二つに分断され農業機械による作業効率が悪くなるため、農作業 効率の向上・合理化を目的として、農地を一つにまとめ裏道を敷地 の端に移動させたり削除したりしていると考えられる。

現在の裏道ゾーンの空間構成は、開拓当時の空間構成と比較する と大きな変化はみられないが、最も特徵的なのは、敷地境界におい て隣家へ通じる通路を新たに設けている点である。これも、第 5 章 で定義・分析する敷地間通路の一つである。他にも、上述の裏道の 削除や農地の一部の貸与など、今日の居住者の生活行動およびライ フスタイルに合わせた新たな環境形成がみられる。

\section{5. 敷地間通路}

\section{5-1. 敷地間通路の定義}

列居型農村集落の近隣関係を分析するために、旧屯田兵村地域の 敷地で夕られた隣家への敷地間通路に着目する。本研究では次の 2 つの条件、(a) 隣接した敷地の間をつないでいること、(b) 形状や幅、 大きさ等の制限はないが少なくとも人が通行できること、を満たす ものを敷地間通路と定義する。

\section{5-2. 形状と位置からみた敷地間通路の種類と特性}

敷地間通路には、素材や幅の違いにより簡易通路と暗渠通路の 2 種類があり、利用目的や利用方法に特徵がみられた。敷地間通路が 存在するゾーンと敷地間通路の種類により、敷地間通路を I 〜 IVの 4 つの型に分類した（図 5)。なお、19 組全ての分析対象において、 表道ゾーンには敷地間通路は存在せず、異なるゾーンを繋ぐ敷地間 通路も存在しなかった。また、図 5 中の数字は分析対象の組番号を 指しており、一つの組が複数の通路をもつ事例があるため、同じ組 番号が複数の型に入っている場合もある。

\section{5-2-1．Ｉ型［宅地ゾーンー簡易通路］(14 組 )}

住宅や農業施設が集まっている宅地ゾーンに、木の板などの幅の 狭い簡易通路や、コンクリートなどの丈夫な素材でできている簡易 通路が設置されている。これらは、比較的安価で軽量な素材のため、

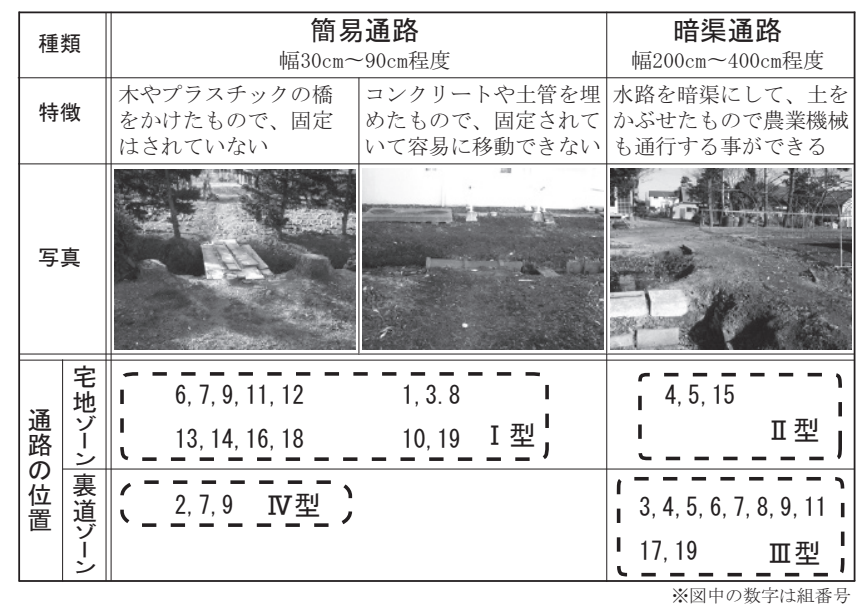

図 5 敷地間通路の種類と位置による分類 
容易に設置することができる。隣家の宅地ゾーンにある住宅を訪問 することを主な目的とし、例えば、家で作った野菜などを渡しにい く、おしゃべりをしにいく、荷物の運搬を手伝いに行くといった利 用である。

\section{5-2-2. II 型 [ 宅地ゾーンー暗渠通路 ］（3 組）}

住宅や農業施設の集まっている宅地ゾーンに、水路を暗渠して土 を盛った通路が設置されたものである。I 型と同様のおしやべりを しにいくなどの交流目的と、共同作業などの農作業目的の両方のた めに利用されている。隣家の宅地ゾーンにある農業施設などの利 用・借用を目的とし、農作業に関係する機械を移動する必要もある ため、幅広の通路が設置されている。

\section{5-2-3. III型 [ 裏道ゾーンー暗渠通路 ] (10 組)}

水田や畑などの農地となっている裏道ゾーンに、水路を暗渠して 土を盛った通路が設置されている。隣家の裏道ゾーンにある水田や 畑などの農地の利用・借用を目的とし、大型の機械を移動する必要 もあるため、幅 $2 \mathrm{~m}$ を超える幅の通路注7) が設置されている。

\section{5-2-4. IV 型 [ 裏道ゾーンー簡易通路 ] (3 組)}

水田や畑などの農地となっている裏道ゾーンに、木の板など幅の 狭い簡易通路を設置している。隣家の裏道ゾーンにある水田や畑な どの農地の利用を目的としているが、人のみが通れる幅の通路が設 置されている。

\section{6. 敷地間通路と隣家関係の分析}

居住者の属性と、敷地間通路の性質によって、19 組の分析対象 の隣家関係のカテゴリー化を行う。居住者の属性は、ライフスタイ ルが異なると考えられる居住者の職業の組み合わせにより捉える。 職業としては、農業従事者、離農者、会社勤務の 3 つとし、それ らを組み合わせて、6つの居住者属性（職業組み合わせ）を設定し た。まず、これら居住者属性（職業組み合わせ）の中に農業従事者 が含まれているかどうかによって、分析対象を分類した。その理由 は、敷地間通路の利用において、分析対象に農業従事者が含まれな い場合には、その分析対象が農作業目的で敷地間通路を利用するこ
とはないからである。ただし、6-4および 6-5 で後述するが、農業 従事者が含まれていない場合でも、III型の通路がある場合には、隣 家ではない近所の住民が農作業目的で敷地間通路を使用することが ある。そして次に、敷地間通路を 1 つのみ設置している場合と複数 設置している場合とで、さらに分類した。その結果、分析対象には、 I 型の通路のみを持っている場合、III ・IV 型の通路を設置している 場合、複数設置している場合の 3 通りがみられたが、III型とIV型を 一つの分類にまとめたのは、敷地間通路の幅や形状が異なり農業機 械が通れるかどうかという違いはあるものの、分析対象の両方とも に農地にあり、農作業目的で使用されていることが理由である。こ のようなカテゴリー化によって、図 6 に示す 5 つのパターンが得ら れた。また、それぞれのパターンの敷地間通路の設置と隣家敷地で の活動状況の概要を、図 7 に示す。

\section{6-1. 農 + ( 農 · 離・会) [ 複数所有型 $](7$ 組 $)$}

居住者属性に農業従事者が含まれていて、敷地間通路を複数設置 しているパターンである。交流目的と農作業目的の両方のために敷 地間通路が利用されている。7 組中 6 組が農作業従事者と非農作業 従事者の職業組み合わせであり、農作業従事者が隣家に裏道ゾーン の農地を借りて農作業を行っている。なお、残りの 1 組は、II 型通 路を宅地ゾーンに複数設置している事例であり、農作業従事者同士

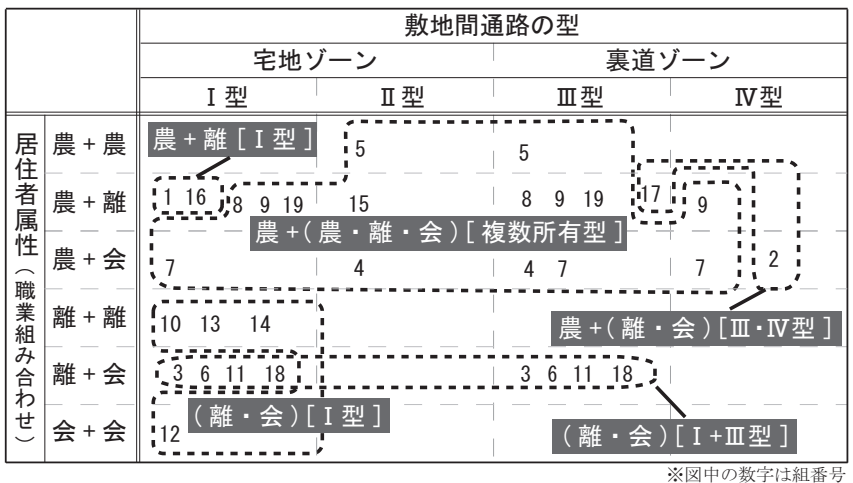

図 6 隣家関係の分類

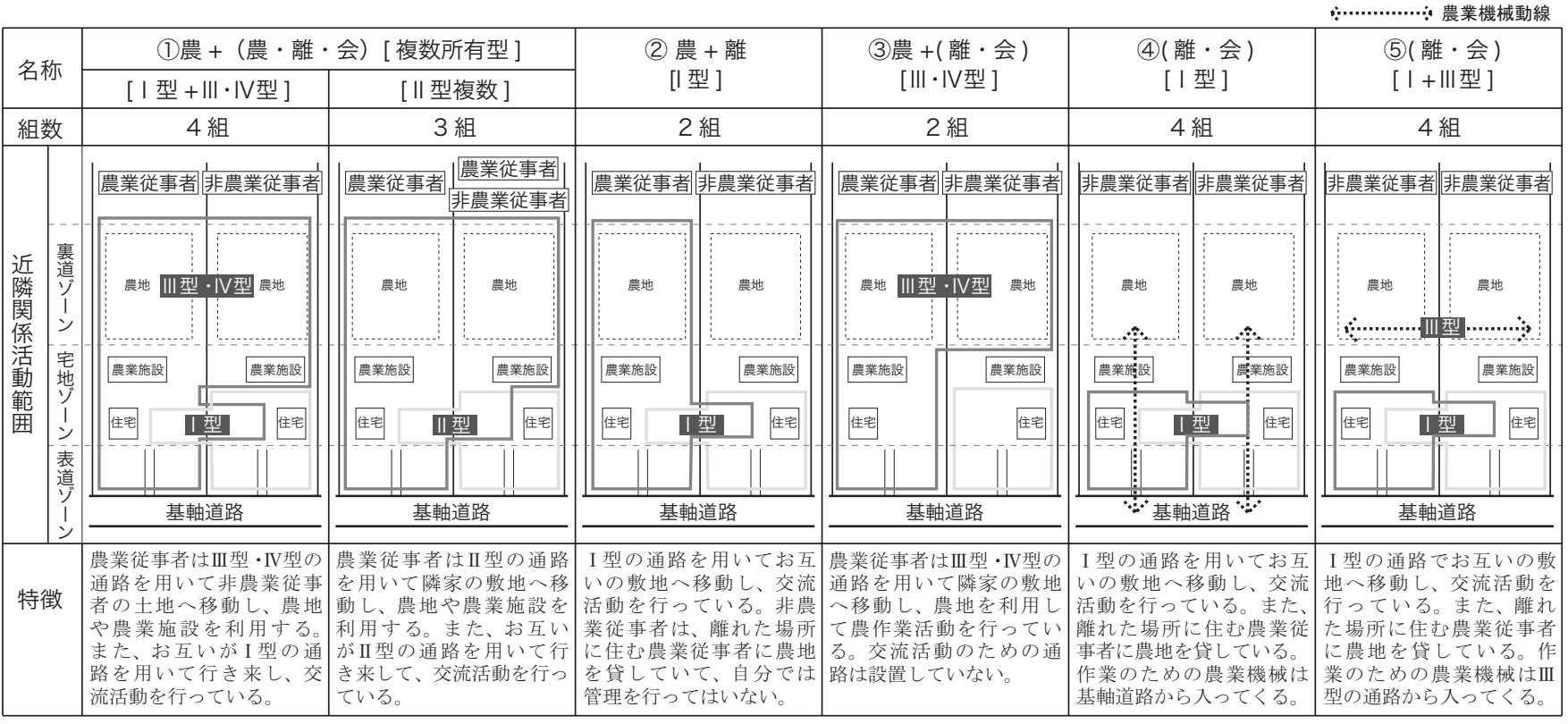

図 7 隣家関係の分類と活動範囲 
の組み合わせである。7 組中 4 組の I 型と III型もしくは I 型と IV 型 の敷地間通路を設置している組は、交流目的と農作業目的で、それ ぞれ異なる敷地間通路を使い分けている。図 8 に示す事例 1 では、 農業従事者が隣家の農地とともに農業施設も借りて農業を行ってお り、隣家の土地の利用度が高い。II 型の敷地間通路を設置している 3 組は、交流目的と農作業目的を兼衫て、II 型の敷地間通路を利用 している。図 8 に示寸事例 2 では、農業従事者は隣家の裏道ゾーン の農地だけでなく、表道ゾーンの土地も借り農地として利用してい るが、冬期間は隣家の表道ゾーンも除雪しているため、相互扶助的 な関係が形成されている。また、離農者は単身で住んでいる高齢者 の場合が多いため、農地や農業施設の貸し借りを通して交流を持つ ことは、自然と高齢者に対する見守り行為へと繋がっている。

\section{6-2. 農 + 離 [I 型 ] (2 組 )}

居住者属性が農業従事者と離農者の組み合わせで、I 型の敷地間 通路のみを設置しているパターンである。農業従事者が裏道ゾーン での農作業を目的として敷地間通路を利用する場合は少ないが、お 互いが I 型の敷地間通路を用いて隣家の敷地一移動し、交流目的も しくは宅地ゾーンでの簡単な農作業を目的として利用している。隣 家に広い農地を借りる場合には大型の機械を必要になるが、そのよ うな機械を移動させることができる幅の広い頑丈な通路がないた め、遠回りをせざるをえなくなり、農作業としては非効率な点が生 じることがある。

\section{6-3. 農 $+($ 離・会) $[$ III $\cdot \mathrm{I}$ 型 $]$ (2 組 )}

居住者属性が農業従事者と離農者の組み合わせで、III型もしくは IV 型の敷地間通路のみを持っているパターンである。農作業目的の ために敷地間通路が設置されている。農業従事者が敷地間通路を用 いて隣家の敷地へ移動し、隣家の裏道ゾーンの農地を借りて、もつ ぱら農作業を目的として利用している。交流目的では利用されない ため、見守り行為などが促されにくいと考えられるが、使用してい ない農地や農業施設を貸し借りするということで、農業という中で
の相互の経済的利点がある。

\section{6-4.（離・会) [ I 型 ] (4 組)}

居住者属性が離農者・会社員など非農業従事者同士の組み合わせ で、I 型の敷地間通路のみを持っているパターンである。お互いが 交流目的で利用するために、人が通れる幅の敷地間通路が設置され ている。裏道ゾーンの農地は、離れた場所に住んでいる農業従事者 に貸しているため、裏道ゾーンにはほとんど立ち入ることはない。 この場合、作業のための農業機械は基軸道路から表道を通って入っ てくることになり、居住者にとっては、機械に付着した泥の掃除を するなどの不都合を抱えることがある。

\section{6-5.（離・会) [ I + II 型 ] (4 組)}

居住者属性が離農者・会社員など非農業従事者同士の組み合わせ で、I 型だけではなく、III型の敷地間通路も持っているパターンで ある。交流目的のために I 型の敷地間通路を利用し、基盤整備によ り設置されたIII型の敷地間通路は使用していない状態となってい る。図 8 に示寸事例 3 では、両者とも裏道ゾーンの農地を貸してお り、以前は農業機械が基軸道路から入ってきていたのだが、それが 日常生活上非常に迷惑であったため、新しく III型の通路が設け、そ れ以降は、農業機械動線の問題が解決されたとのことであった。

\section{7. まとめ}

本研究では、屯田兵村の開拓当時の空間構成と現在の空間構成を 踏まえ、特に居住者の敷地間通路の活用の実態を詳細に把握するこ とで、居住者の環境形成の仕方と隣家関係の特徵を分析することを 試みた。その成果として、現代の農村集落の居住者の、地域社会あ るいは農村コミュニティに対する関わり方の一端を示し得たと考え る。以下に、その要点をまとめる。

(1) 農業施設の種類や数は、農業従事者と非農業従事者で異なり、 多様な配置がみられ、住宅や車庫を基軸道路の近くに設置した り、敷地の中心にあった裹道を端に移動させたり、あるいはな

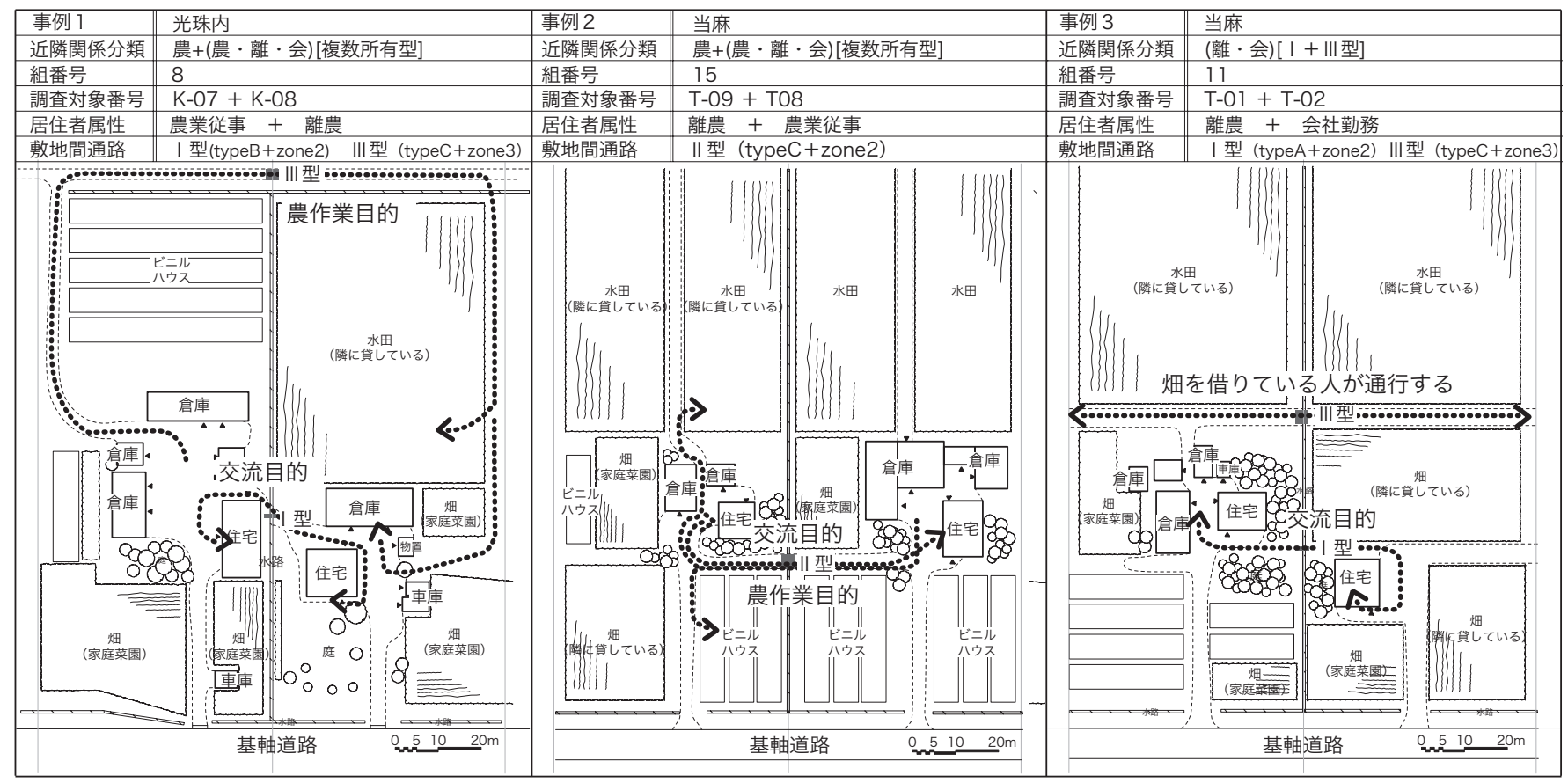

図 8 近隣関係の具体的事例 
くしたりなど、居住者の生活行動・ライフスタイルに合わせて 合理的・効率的な環境形成が行われていた。

（2）開拓当時に設置された横道に関しては、農業の合理性と効率性 の向上を目的として水路を設けたため、一時はなくなってし まったが、居住者の様々な生活要求により、形式は異なるが、 横道のような敷地間通路が再び設置されていた。敷地間通路は、 位置と形状により 4 つに分類することができ、さらに居住者属 性から敷地間通路を通しての隣家関係を 5 つのパターンに分類 することができた。

（3）隣家関係については、交流目的と農作業目的がみられ、敷地間 通路の設置により隣家と行き来しやすい環境が形成され、その 中で目的に合わせ敷地間通路を複数設置することで、農作業空 間と非農作業空間を分離し、利便性の高い環境を創出している。

(4) 農業従事者と非農業従事が隣接して住む場合、非農業従事者の 余剩となっている農業施設や農地を借りることで、農作業の効 率だけでなく、経済的な合理性も実現している。このような居 住者のマネジメントの工夫により、敷地の制限が多い屯田兵村 においても、必ずしも十分ではないが今日の北海道の大規模な 農業体制に対応できている。

（5）非農業従事者の中には、単身で住んでいる高齢者も少なくない ため、余剩な施設を隣家へ貸すことが、日常的な見守り行為の 誘発へと繋がっている。高齢者にとっては、安心して定住しや すい環境が形成されている。

北海道では、農作業の近代化とともに農業の大規模化や農地の集 約化が推進され、今日では、開拓当初に整備された屯田兵村の空間 構成とは全く異なる農村の景観が広がっている。旧屯田兵村地域 は、その兵役システムを明確に反映した敷地形状と施設配置の計画 性から、現代の農村集落における人々の生活に何らかの不具合を生 じていると推測されるのが自然である。しかしながら、屯田兵村の 横道に始まる敷地間通路に注目した居住者の活動之隣家関係の分析 を通じて、屯田兵村が持っていた空間構成、つまり、間口の狭い敷 地が軸上に並ぶ計画が敷地間通路の設置を促し、むしろ現代の多様 な居住者属性のライフスタイルと空間の使い方に対して柔軟に対応 していること、そして、農地や農業施設を合理的に貸し借りでき、 農業従事者だけでなく高齢者や会社勤務者などの非農業従事者が積 極的に隣家と交流できるなど、様々な隣家関係パターンを形成して いることが明らかとなった。このように、農業政策がさらなる大規 模化へと集中寸る中で、旧屯田兵村地域の豊かな環境形成の営みを 明らかにし、農村で生活する人々の工夫と現代コミュニティの実態 を示したことが、本研究の意義ある成果であると考える。

なお、本研究では、4つの旧屯田兵村地域の 32 件 19 組を分析対 象としたが、それぞれの地域の対象件数にばらつきがあったため、 地域別の比較分析は行わなかった。具体的には、調查対象の組番号 でいうと、組番号 1 と 2 が茶志内、 3 から 10 が光珠内、 11 から 17 が当麻、18 と 19 が一已であった。しかしながら、これら 4 つの地 域には、同じ屯田兵村という起源をもっていたとしても、その後の 地域の市街化の進展や農業構造の変化等においてそれぞれに特徴が あり、それらが何らかの地域コミュニティと環境形成活動に影響を 与えていることは十分に予想される。今後は、そのような地域特性 別の調查研究にも取り組んでいきたい。それを踏まえ、農村集落の
居住者が地域社会に求めていることをより総合的に検討すること で、北海道におけるサスティナブルな農村コミュニティの考察をさ らに深めていきたい。

\section{謝辞}

調查に協力いただいた旧屯田兵村地域の居住者の方々、各種資料 を提供して下さった各市町役場の関係各位に深く感謝いたします。 また、研究の端緒において熱心に指導していただいた故・野口孝博 先生に心より感謝いたします。

注

注 1）農作業のための耕地（農地）と居住のための宅地が合わさった敷地

注 2) 東旭川兵村史等の史料によって、「表道・前道」「裹道・耕作道・作道」「横 道・隣道・隣家道」などの名称がつけられていたことがわかっているが、 本研究では、ヒアリングで最も多く聞かれた名称を用いる。

注 3）高志内兵村であった、現在の美唄市光珠内町地域。

注 4) 東当麻兵村・西当麻兵村であった、現在の当麻町地域。

注 5）北一已兵村・南一已兵村であった、現在の深川市一已町地域。

注 6） 屯田兵村を契機とした集落は、現在水稲農業を中心に行っているため、 農業基盤整備で水路整備が行われた。

注 7）このような通路は、農業基盤整備でつくられる場合が多い。

\section{参考文献}

1）伊藤庸一：農村集落における社会集団の重層的な構成に関寸る考察，日本 建築学会計画系論文集，第 403 号，pp. 105-113，1989.9

2）鎌田元弘・坂本淳二・細谷健太郎・西村昌彦：混住化農村地域における新 住民行政区のコミュニティ形成 混住化による再編過程を経た行政区を事 例として, 日本建築学会計画系論文集，第 555 号，pp. 215-222，2002.5

3）柳田良造・重村力：屯田兵村の空間構成における計画原理，日本建築学会 計画系論文集，第 594 号, pp. $61-68,2005.8$

4）柳田良造・重村力：ルーラルデザインしての屯田兵村の計画手法に関する 研究，日本建築学会計画系論文集，第 600 号, pp. 89-96，2006.2

5）高橋美寛・久保勝裕・白木里恵子：屯田入植地における歷史ネットワーク の実態に関する研究，日本都市計画学会都市計画論文集，Vol. 41，No. 3, pp. 923-928，2006. 10

6) 足達富士夫 : 北海道農村住宅変貌史の研究, 北海道大学図書刊行会, 1995. 4

（2008年 7 月 3 日原稿受理，2009年 1 月29日採用決定） 